\title{
Nutritional divergence in genotypes of forage peanut
}

\section{Alexandre Lima Ferreira ${ }^{1}$, Rogério Martins Maurício ${ }^{2}$, Luiz Gustavo Ribeiro Pereira ${ }^{3}$, José Augusto Gomes Azevêdo ${ }^{4}$, Leandro Silva Oliveira ${ }^{5}$, José Marques Pereira ${ }^{6}$}

\author{
1 Universidade Federal de Minas Gerais. \\ 2 Universidade Federal de São João Del Rei. \\ 3 Embrapa Gado de Leite. \\ ${ }^{4}$ Universidade Estadual de Santa Cruz. \\ ${ }^{5}$ Embrapa Caprinos e Ovinos. \\ ${ }^{6}$ Universidade Estadual de Santa Cruz/Comissão Executiva do Plano da Lavoura Cacaueira.
}

\begin{abstract}
The objective of this study was to evaluate the nutritional divergence between ten genotypes of forage peanut, based on chemical composition as well as fermentation and in vitro degradation kinetic characteristics. Treatments consisted of ten genotypes of Arachis pintoi, namely eight accessions (31135, 30333, 15121, 31828, 15598, 31534, 13251 and 31496) and two cultivars (cv. Belmonte and cv. Amarillo). The genotypes were harvested in each plot at a height of $3 \mathrm{~cm}$ from the ground, in 42-day intervals, during the time of heaviest rainfall. For the multivariate analysis the following variables, the following were used: crude protein, neutral detergent fiber, potential degradation in 48 hours, degradation rate of insoluble potentially degradable fraction and degradation rate of non-fibrous carbohydrate. The application of the hierarchical clustering analysis, using the Euclidian distances matrix of standardized averages allowed for the identification of five homogeneous groups. Among them, the accessions 31828, 31534, 15121 and cv. Belmonte stood out nutritionally among the remaining genotypes evaluated, depicting as promising for the utilization in ruminant feeding.
\end{abstract}

Key Words: chemical composition, gas production, multivariate analysis

\section{Introduction}

The biggest Brazilian differential in the production of beef at competitive costs is the fact that climatic conditions allow for the use of pastures year round. Within this tropical environment favorable to pasture growth, the challenge is to fulfill the nutritional requirements of grazing animals, since animal production is a direct response of the quantity and quality of the feed consumed (Minson, 1982).

Leguminous plants are forages that play a relevant role in animal production, exerting an important function due to their high protein content and to their capacity of biologically fixating atmospheric nitrogen. These characteristics enable a qualitative and a quantitative increase in forage production. Studies done in different Brazilian ecosystems (Pizarro et al., 1992; Carneiro et al., 2000) identified accessions of Arachis pintoi with superior yield and quality to the cultivar Amarillo, the most disseminated among Central and South America producers.

Agronomical evaluations based on productivity, occurrence of pests and diseases, seed production, compatibility with forage grass and arboreal species as well as perennial shrubs and, above all, resistance to grazing have been used in recommendations of promising Arachis genotypes in the production systems of grazing cattle (Valentim et al., 2003). However, little is known about the differences in the nutritional potential among genotypes of forage peanut (Arachis pintoi) for ruminants.

Azevedo et al. (2003), adapting the term genetic divergence to nutritional divergence, showed that it is possible to identify within a group of tropical forage varieties, one which is more nutritionally promising, using as a basis, the simultaneous evaluation of important discriminatory variables for ruminant nutrition. The evaluation of nutritional divergence in forage peanut genotypes presents potential to aid in the selection of superior genotypes, since nutritional value directly influences animal performance.

Within this context, the objective here was to evaluate the nutritional divergence of ten genotypes of Arachis pintoi, aiming at identifying promising genotypes for ruminant feeding.

\section{Material and Methods}

In the experimental field station of Animal Science of the Extreme South (ESSUL) belonging to the Executive Commission for the Cocoa Culture Plan (CEPLAC), located 
at Itabela ( $16^{\circ} 39^{\prime} \mathrm{S}$ and $\left.39^{\circ} 30^{\prime} \mathrm{W}\right)$, in the extreme south of Bahia, an experiment was implemented in order to evaluate the adaptability and productivity of Arachis genotypes using a randomized block design, with four repetitions (Ruiz \& Santana, 2004).

The area is under the domain of the ecosystem "Mata Atlântica" and the local climate is a transition between the Af and Am types, according to the Köppen classification, with annual rainfall of $1,312 \mathrm{~mm}$ and average temperature of $23^{\circ} \mathrm{C}$, with no defined dry season. The soil is a sandy (>700 g of sand/Kg) Ultisol (Typical Paleudult fine-loamy, kaolinitic, isohyperthermic), in the superficial $20 \mathrm{~cm}$. Its average chemical characteristics, when the experiment was implemented were: $\mathrm{pH}$ in $\mathrm{H}_{2} \mathrm{O}=4.9 ; \mathrm{P}=1 \mathrm{mg} / \mathrm{dm}^{3}$; $\mathrm{Ca}$, $\mathrm{K}$ and $\mathrm{Al}=0.6,0.5$ and $0.1 \mathrm{meq} / 100 \mathrm{~g}$, respectively.

At set up, the soil was plowed at $0.20 \mathrm{~m}$, conveniently harrowed and furrowed. At the bottom of the furrow, $40 \mathrm{~kg} / \mathrm{ha}$ of $\mathrm{P}_{2} \mathrm{O}_{5}$ were applied, using the fertilizer superphosphate ( $18 \%$ of $\mathrm{P}_{2} \mathrm{O}_{5}$ ) as a source for this nutrient. The planting was done with vegetative material (stolons). One year after sampling had begun, for determination of dry matter (DM) production, fertilizer replenishment was done with $40 \mathrm{~kg} / \mathrm{ha}$ of $\mathrm{P}_{2} \mathrm{O}_{5}$.

Plots were set up with an area of $7.5 \mathrm{~m}^{2}(3 \times 2.5 \mathrm{~m})$, in 5 rows, at a $0.50-\times 0.50$-m spacing.

For biomass sampling, the genotypes were harvested in each plot at a height of $3 \mathrm{~cm}$ from the ground, in 42-day intervals. The experimental period comprehended the time of heaviest rainfall, corresponding to the months between December, 2000 and April, 2001.

Climatic data relative to the experimental period were obtained from the Animal Husbandry Experimental Station of the Extreme South (ESSUL), located in the municipality of Itabela - BA (Table 1).

Ten genotypes of Arachis pintoi were used in this experiment, namely eight accessions (31135, 30333, 15121, 31828, 15598, 31534, 13251 e 31496) and two cultivars (cv. Belmonte and cv. Amarillo).
After collection and weighing of the green forage from the usable area $\left(2 \mathrm{~m}^{2}\right)$, the material was dried in an forced ventilation oven at $55^{\circ} \mathrm{C}$ for 72 hours, ground in a Willey type mill with 1-mm mesh sieve and packaged in polyethylene jars for posterior analysis.

Analysis were performed in order to determine the contents of dry matter (DM), ash, ether extract (EE), crude protein (CP), acid detergent insoluble protein (ADIP), and the concentrations of neutral detergent fiber (NDF), acid detergent fiber (ADF) as described by Silva \& Queiroz (2002). Total carbohydrate (TC) was calculated through the formula TC $=100-(\% \mathrm{CP}+\% \mathrm{EE}+\%$ Ash $)$ and non-fibrous carbohydrate (NFC), from the formula: NFC $=100-(\% \mathrm{CP}+$ $\%$ NDFap + \%EE + \%Ash), according to Hall (2000), where NDFap represents neutral detergent fiber corrected for ash and protein and the other variables, as previously described.

The genotypes were further evaluated by the in vitro semi-automatic gas production technique (Mauricio et al., 1999) at the gas production laboratory from the Faculty of Veterinary Medicine at UFMG. For this evaluation, one gram of sample from these materials was incubated in glass flasks with capacity for $160 \mathrm{~mL}$, to which $10 \mathrm{~mL}$ of ruminal inoculate and $90 \mathrm{~mL}$ of culture media were manually added, according to Theodorou et al. (1994). The flasks were sealed with rubber corks $(14 \mathrm{~mm})$. The ruminal inoculate was collected from a Jersey steer fitted with a ruminal cannula, kept under a diet of corn silage and $1 \mathrm{~kg} /$ day of commercial concentrate with $22 \% \mathrm{CP}$. The pressure readings were taken at 2, 4, 6, 8, 10,12, 14, 17, 20, 24, 28, 34, 48, 72 and 96 hours after inoculation. Pressure results were used for the calculation of gas volume, using the equation described by Mauricio et al. (2003).

Fermentation residues were obtained through the filtration of residue from the fermentation flasks in filtering crucibles (porosity 1). These residues were dried at $105^{\circ} \mathrm{C}$ down to a constant weight and the results were used for the calculation of in vitro degradability of DM.

Table 1 - Monthly climatic data average in the period between October 2000 and April 2001 in Itabela, Bahia

\begin{tabular}{|c|c|c|c|c|c|c|c|}
\hline \multirow[t]{2}{*}{ Year } & \multirow[t]{2}{*}{ Month } & \multirow{2}{*}{$\begin{array}{l}\text { Precipitation } \\
\qquad(\mathrm{mm})\end{array}$} & \multicolumn{3}{|c|}{ Temperature $\left(\mathrm{C}^{\circ}\right)$} & \multirow{2}{*}{$\begin{array}{l}\text { Evaporation } \\
\qquad(\mathrm{mm})\end{array}$} & \multirow{2}{*}{$\begin{array}{c}\text { Relative air humidity (\%) } \\
\text { (\%) }\end{array}$} \\
\hline & & & Max. & Min. & Avg. & & \\
\hline 2000 & October & 27.7 & 29.7 & 19.0 & 23.4 & 5.4 & 79.5 \\
\hline 2000 & December & 200.3 & 29.7 & 21.8 & 24.9 & 5.4 & 80.6 \\
\hline 2001 & January & 218.1 & 30.1 & 21.4 & 24.9 & 5.0 & 83.1 \\
\hline 2001 & February & 120.6 & 31.1 & 21.4 & 25.0 & 5.9 & 82.4 \\
\hline
\end{tabular}

Max. - maximum; Min. - minimum; Avg. - average. 
For the evaluation of degradation kinetics (gravimetric technique), the model proposed by Sampaio et al. (1995) was used:

$Y=A-B * \exp (-c * t)$

where: $\mathrm{Y}$ is the $\mathrm{DM}$ residue at time $\mathrm{t}$; $\mathrm{A}$, the potential degradation of the DM fraction; $\mathrm{B}$, the insoluble potentially degradable fraction; exp, the base of neperian logarithms; $\mathrm{c}$, the degradation rate of fraction $\mathrm{B}$ by unit of time (/h); and $\mathrm{t}$, the incubation time.

For ruminal fermentation kinetics, obtained by the gas production technique, the kinetic variables for fibrous carbohydrate (FC) and non-fibrous carbohydrate (NFC) were estimated by the two-pool logistic model proposed by Schofield et al. (1994), adjusted to the gas cumulative production curves, as described:

$V=V f 1 /(1+\exp (2-4 * C 1 *(T-L)))+V f 2 /(1+\exp (2-$ $4 * C 2 *(T-L)))$

where: Vf1 is equivalent to the maximum volume of gases in the NFC fraction; $\mathrm{C} 1$, to the degradation rate (/h) of the NFC fraction; Vf2, to the maximum volume of gases in the FC fraction; $\mathrm{C} 2$, to the degradation rate (/h) of the FC; and T and $\mathrm{L}$, to the incubation times (h) and to the latency (h), respectively.

The nonlinear models used to describe the degradation profiles obtained by gravimetric and metabolic pathways were fitted by the iterative algorithm of Gauss-Newton.

Univariate statistical analysis was performed through the program SAEG (System for Statistical and Genetic Analysis, version 9.1). Means were compared using the Tukey test at $5 \%$ probability. Multivariate analysis was performed using the computational resources of the Minitab 16 program, where the agglomerative hierarchical cluster analysis took place, by the complete linkage method, with the standardized average Euclidean distance as a basic measure of dissimilarity.

\section{Results and Discussion}

No differences were observed for DM, ADICP, ADF, EE or NFC $(\mathrm{P}>0.05)$, with mean values of 16.8 ; 13.0; 38.6; 1.6 and $19.8 \%$, respectively (Table 2 ).

Mean values relative to variables ash, $\mathrm{CP}, \mathrm{NDF}, \mathrm{TC}$ and Deg48 differed between the treatments evaluated. CP contents were elevated, with average value of $24.8 \%$. Average values for NDF, ADF and TC ranged from 50.2 to $55.5 ; 36.3$ to 41.8 and from 68.7 to $72.3 \%$, respectively. The greatest CP and TC contents were found for genotypes 30333 and cv. Belmonte, respectively, while the lowest NDF content was found for accession 31496. Crude protein, NDF and ADF contents described by Silva et al. (2009), while evaluating forage peanut with cutting age of 60 days, were inferior to those observed in this study. However, superior values were observed for EE (1.9\%), TC (78.9\%) and NFC (26.5\%) contents.

Similar results for $\mathrm{CP}$ and inferior ones for ADF were found by Affonso et al. (2007), after studying the effect of cutting management $(1,2,3$, 4 or 5 cuttings) during springsummer, on the nutritional value of this forage. These authors report concomitant elevation of CP (18 to 26\%) and reduction of ADF (26 to 31\%) contents as cutting frequency increased.

Dry matter and ash contents obtained were relatively low when compared with those reported in the literature (Silva et al., 2009; Valadares Filho et al., 2006; Staples et al., 1997). Low DM and ash contents were due to the fact that the genotypes evaluated were harvested at a lower cutting interval (42 days), when compared with the studies cited (60 to 183 days). According to Nascimento Júnior \& Vilela (1995), the cutting represents a moment of stress for the plant, characterized by a drop in reserve carbohydrate content, interruption in root growth and a decrease in nutrient absorption.

The differences observed relative to chemical composition are mainly due to variations in edaphoclimatic factors in the regions where the evaluations took place, favoring a greater or lower speed in development and, consequently, early or late maturation of the forages; genotype choice, given the intrinsic variation in chemical composition between them; and the cutting intervals employed.

Nascimento et al. (2010) evaluated the effect of cutting management (21, 42, 63 and 84 days) on the quality of forage obtained from forage peanut. They observed an increase in the amount of NDF and ADF contents and a reduction of CP content and in vitro digestibility as cutting intervals increased, as a consequence of the relationship leaf and petiole per stem. These authors reported that the best response for nutritional value was obtained in the cutting at 42 days of plant growth.

Lenzi et al. (2009), studying production and quality of coastcross pasture (Cynodon dactylon) intercropped with peanut forage or not, reported that, regardless of the season, there was no difference in the chemical and in vitro digestibility of Arachis pintoi, demonstrating the ability of this legume to maintain good nutrition throughout the year.

Deg48 values ranged from 43.1 to $53.1 \%$, showing differences only between cultivars cv. Amarillo and cv. 
Belmonte; however, the remaining genotypes did not differ (Table 2). In the present study, high levels of NDF were negatively correlated $(r=-0.73)$ with Deg48. According to Van Soest (1994), the lower the fiber content of a forage, the higher its digestibility, since most of the indigestible components of a feed are found in this fraction.

High positive correlation $(r=0.72)$ was also found between the levels of $\mathrm{CP}$ and acid detergent insoluble protein (ADIP), indicating that higher levels of $\mathrm{CP}$ tend to increase the protein fraction bound to ADF, which represents the unavailable fraction.

For the adjusted parameters of dry matter in vitro degradation kinetics (Table 3), the values for insoluble potentially degradable fraction (B) and for potential degradation of the DM fraction (A) ranged from 33.2 to 51.5 and 46.7 to $52.2 \%$, respectively. Cultivar Amarillo had the lowest average value and cv. Belmonte had the highest one for potential degradation, while the highest values for fraction B were observed for accession 31534. Degradation rates $(\mathrm{kd})$ were high, with overall average of $0.066 / \mathrm{h}$ for the genotypes evaluated.

Evangelista et al. (2002) studied the in situ degradability of 15 alfalfa cultivars, and found similar mean values for fraction B (38.0 to $44.4 \%)$ and higher for kd rate $(0.078$ to $0.124 / \mathrm{h}$ ) and potential degradation (78.4 to $81.6 \%$ ). Veloso et al. (2006) evaluated in situ DM degradation for the follicles of tropical legumes leucena (Leucaena leucocephala) and guandu (Cajanus cajan) as well as for the leaves of manioc (Manihot sculenta). These authors reported higher values for fraction B (62.9, 43.4 and 73.0\%) and $\mathrm{Kd}$ rates $(0.060,0.039$ and $0.106 / \mathrm{h})$ for the forages, respectively.

The latency (L) ranged from 4.4 to 5.5 hours, showing relatively low and desirable values (Table 4) compared with those reported by Sá et al (2011) for Brachiaria brizantha (12.9 to $14.6 \mathrm{~h}$ ), with ages ranging from 28 to 54 days, and by Campos et al. (2000) for corn silage (6.2 to $9.1 \mathrm{~h}$ ) in a period of 48 hours. The fiber fraction is directly related to most of the events involved in this parameter.

The larger gas volumes produced for the rapid degradation fraction (VF1) were obtained for cv. Belmonte, followed by accession 31534 and cv. Amarillo (Table 4). These high values for VF1 are due to the higher NFC content presented by these genotypes (Table 2), conferring greater availability of fermentable substrate and providing greater gas production for this fraction. Degradation rates for the rapidly degradable fraction (C1) were low, averaging $0.068 / \mathrm{h}$, since reports of values from 0.1 to $0.2 / \mathrm{h}$, are frequent (Cabral et al., 2003; Senger et al., 2007; Detmann et al., 2009). The highest gas productions from the fermentation of the slowly degradable fraction (VF2) were found for accessions 31828 and 31534.

Table 2 - Average contents of chemical composition, degradability and gas production as a function of the genotypes of Arachis

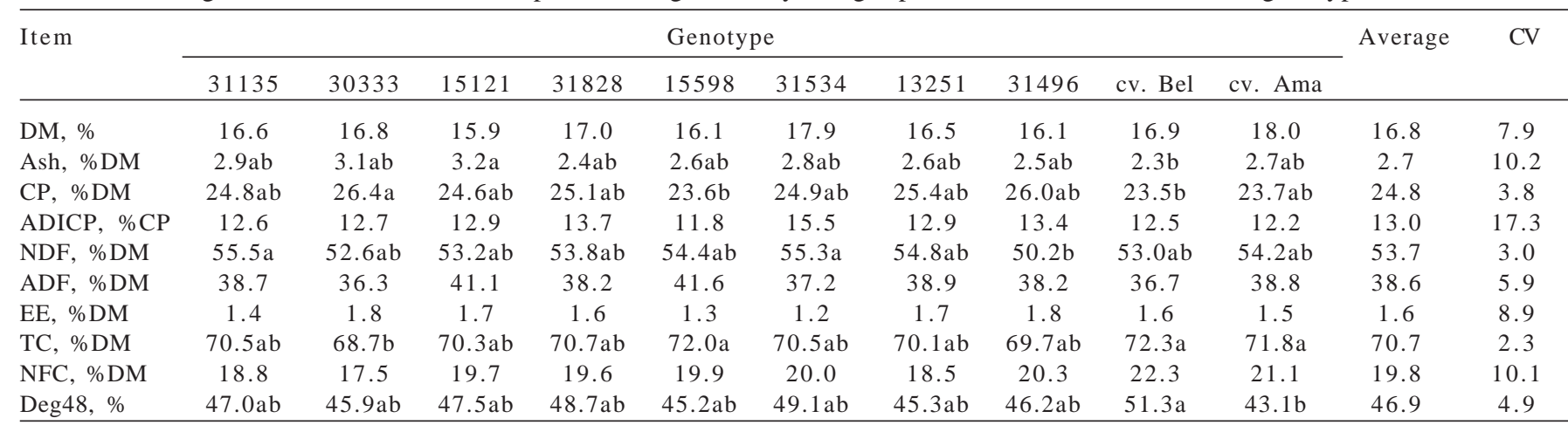

ADF - acid detergent fiber; EE - ether extract; TC - total carbohydrates; NFC - non-fibrous carbohydrates; Deg48 - in vitro digestibility in 48 hours of incubation; $\mathrm{CV}$ - coefficient of variation in \%; cv. Bel - cv. Belmonte; cv. Ama - cv. Amarillo.

Means followed by different letters in each row differ statistically by the Tukey test at a 5\% probability level.

Table 3 - Average of adjusted parameters relative to in vitro degradation kinetics of dry matter relative to the genotypes of Arachis

\begin{tabular}{|c|c|c|c|c|c|c|c|c|c|c|c|}
\hline \multirow[t]{2}{*}{ Item } & \multicolumn{10}{|c|}{ Genotype } & \multirow[t]{2}{*}{ Average } \\
\hline & 31135 & 30333 & 15121 & 31828 & 15598 & 31534 & 13251 & 31496 & cv. Bel & cv. Ama & \\
\hline A (\%) & 48.3 & 47.4 & 48.4 & 49.9 & 48.3 & 50.0 & 47.5 & 50.1 & 52.2 & 46.7 & 48.9 \\
\hline B (\%) & 34.0 & 36.8 & 41.7 & 44.9 & 35.7 & 51.5 & 36.1 & 33.2 & 44.2 & 34.8 & 39.3 \\
\hline $\mathrm{Kd}(/ \mathrm{h})$ & 0.055 & 0.071 & 0.082 & 0.075 & 0.051 & 0.087 & 0.064 & 0.045 & 0.081 & 0.047 & 0.066 \\
\hline $\mathrm{R}^{2}$ & 0.885 & 0.882 & 0.889 & 0.891 & 0.938 & 0.903 & 0.913 & 0.906 & 0.938 & 0.852 & - \\
\hline
\end{tabular}

A - potential degradation of the DM fraction; B - insoluble potentially degradable fraction; Kd - degradation rate of fraction B; cv. Belm. - cv. Belmonte and cv. Ama - cv. Amarillo. 
Degradation rates for the slowly degradable fraction (C2) had a mean value of $0.018 / \mathrm{h}$. The highest gas production for the rapidly degradable fraction obtained for the accessions evaluated had been predicted by Schofiled \& Pell (1995), according to whom the contribution of gas production from the NFC fraction would be greater for legumes than for the grasses.

Campos et al. (2000), while evaluating alfalfa hay, found the following values for the fermentation kinetic parameters: VF1 = $95 \mathrm{~mL} ; \mathrm{C} 1=0.17 \mathrm{~h}^{-1} ; \mathrm{L}=1.5 \mathrm{~h} ; \mathrm{VF} 2=107 \mathrm{~mL} ; \mathrm{C} 2=$ $0.031 \mathrm{~h}^{-1}$ and PG $48=203 \mathrm{~mL} / \mathrm{g}$ DM. For all kinetic parameters, superiority is observed for the alfalfa hay when compared with the genotypes of Arachis evaluated. This discrepancy can be attributed in part to differences in the chemical composition of these two legumes, since the referenced alfalfa hay had lower levels of CP (20.9\%), NDF (33.8\%) and ADF (25.8\%), which allows for the inference that alfalfa probably had a higher fibrous fraction degradability and a higher contribution of NFC for the production of gases.

The largest volumes of gas produced within a 24-hour fermentation period in the DM fraction were obtained for genotypes cv. Belmonte and 31534, with the respective values of 119.9 and $113.8 \mathrm{~mL} / \mathrm{g} \mathrm{DM}$, while smaller volumes were observed for the accessions 30333 and 31496, with values of 85.7 and $94.9 \mathrm{~mL} / \mathrm{g}$ DM, respectively (Figure 1).

After the of 48 hours of fermentation period, gas production of TC tended to stabilize, reaching values above $90 \%$ of total gas production for all genotypes. Gas production of NFC increased gradually until the period of 17 hours of fermentation, tending to stabilize after 24 hours of fermentation, while the highest gas production from FC occurred in the period between 24 and 36 hours of fermentation. The fermentation of cv. Belmonte and accession 31534 provided greater total gas production; therefore, it can be inferred that for these genotypes, the fiber fraction was more extensively degraded. The opposite can be observed for accession 30333, which provided a lower volume of gas (Figure 1).
According to Getachew et al. (2004), the amount of gases produced by incubating a feedstuff reflects the production of short chain fatty acids, which are the main source of energy for ruminants. The gases come directly from the microbial degradation of food, and indirectly from the reaction of the buffer with the acids generated as a result of fermentation.

In the evaluation of the nutritional divergence, all variables present in this study were used in order to carry out a cluster analysis, as a result of which, those with the highest power of discrimination were selected. Based on the transformation of discriminatory variables $\mathrm{CP}$, NDF, Deg48, Kd and C1 with the highest contribution to the distinction of the accessions evaluated, the dendrogram of similarity was obtained. Thus, hierarchy levels were established and the ten genotypes of forage peanut were grouped in different homogeneous groups based on the similarity expressed by the standardized average Euclidean distance (Figure 2).

Proceeding to the analysis of the results of agglomerative hierarchical clustering, one can observe the formation of two large dissimilar groups (Figure 2). Group 1, consisting of the genotypes 31135, 13251, 15121, 31828, 31534 and cv. Belmonte, presenting 39\% similarity between themselves and Group 2, composed of the genotypes 30333, 31496, 15598 , and cv. Amarillo, with only $27 \%$ similarity.

Carrying out the partition of the dendrogram (Figure 2), done in a subjective way, assuming a $70 \%$ similarity, the formation of five subgroups was detected.

Subgroup I, represented by accessions 31135 and 13251, had 91\% similarity, characterized by high levels of CP and NDF, high C1 rates and low Kd rates (Table 5). Subgroup II had accession 15121 as its single component and was the subgroup which distanced itself the most in relation to the remaining ones, with the largest average Euclidean distance (2.61) and greater degree of dissimilarity between the genotypes evaluated. The highest rates for $\mathrm{Kd}$ and $\mathrm{C} 1$ and the high level of Deg48 contributed to the formation of this isolated subgroup (Table 5).

Table 4 - Average of adjusted parameters relative to gas production kinetics of non-fibrous carbohydrate (NFC) and of fibrous carbohydrate (FC) in a 48 hour period relative to the genotypes of Arachis

\begin{tabular}{|c|c|c|c|c|c|c|c|c|c|c|c|}
\hline \multirow[t]{2}{*}{ Item } & \multicolumn{10}{|c|}{ Genotype } & \multirow[t]{2}{*}{ Average } \\
\hline & 31135 & 30333 & 15121 & 31828 & 15598 & 31534 & 13251 & 31496 & cv. Bel & cv. Ama & \\
\hline L (h) & 4.8 & 4.8 & 4.4 & 5.0 & 5.5 & 4.9 & 4.5 & 4.8 & 4.9 & 4.7 & 4.8 \\
\hline VF1 (mL) & 89.7 & 75.0 & 89.3 & 94.8 & 93.4 & 101.6 & 89.1 & 84.6 & 106.0 & 101.0 & 92.5 \\
\hline C1 $\left(h^{-1}\right)$ & 0.070 & 0.069 & 0.074 & 0.066 & 0.067 & 0.065 & 0.071 & 0.066 & 0.068 & 0.063 & 0.068 \\
\hline VF2 (mL) & 45.3 & 39.7 & 41.4 & 50.8 & 48.3 & 50.2 & 45.7 & 41.2 & 51.3 & 47.6 & 46.2 \\
\hline C2 $\left(h^{-1}\right)$ & 0.018 & 0.017 & 0.019 & 0.018 & 0.018 & 0.018 & 0.018 & 0.017 & 0.018 & 0.017 & 0.018 \\
\hline $\mathrm{R}^{2}$ & 0.989 & 0.920 & 0.912 & 0.982 & 0.994 & 0.988 & 0.985 & 0.911 & 0.997 & 0.995 & - \\
\hline
\end{tabular}

VF1 - maximum volume of gases for the NFC fraction; C1 - degradation rate for the NFC fraction; L - latency; VF2 - maximum volume of gases for the FC fraction; C2 - degradation rate for the FC fraction; cv. Belm. - cv. Belmonte and cv. Ama - cv. Amarillo. 

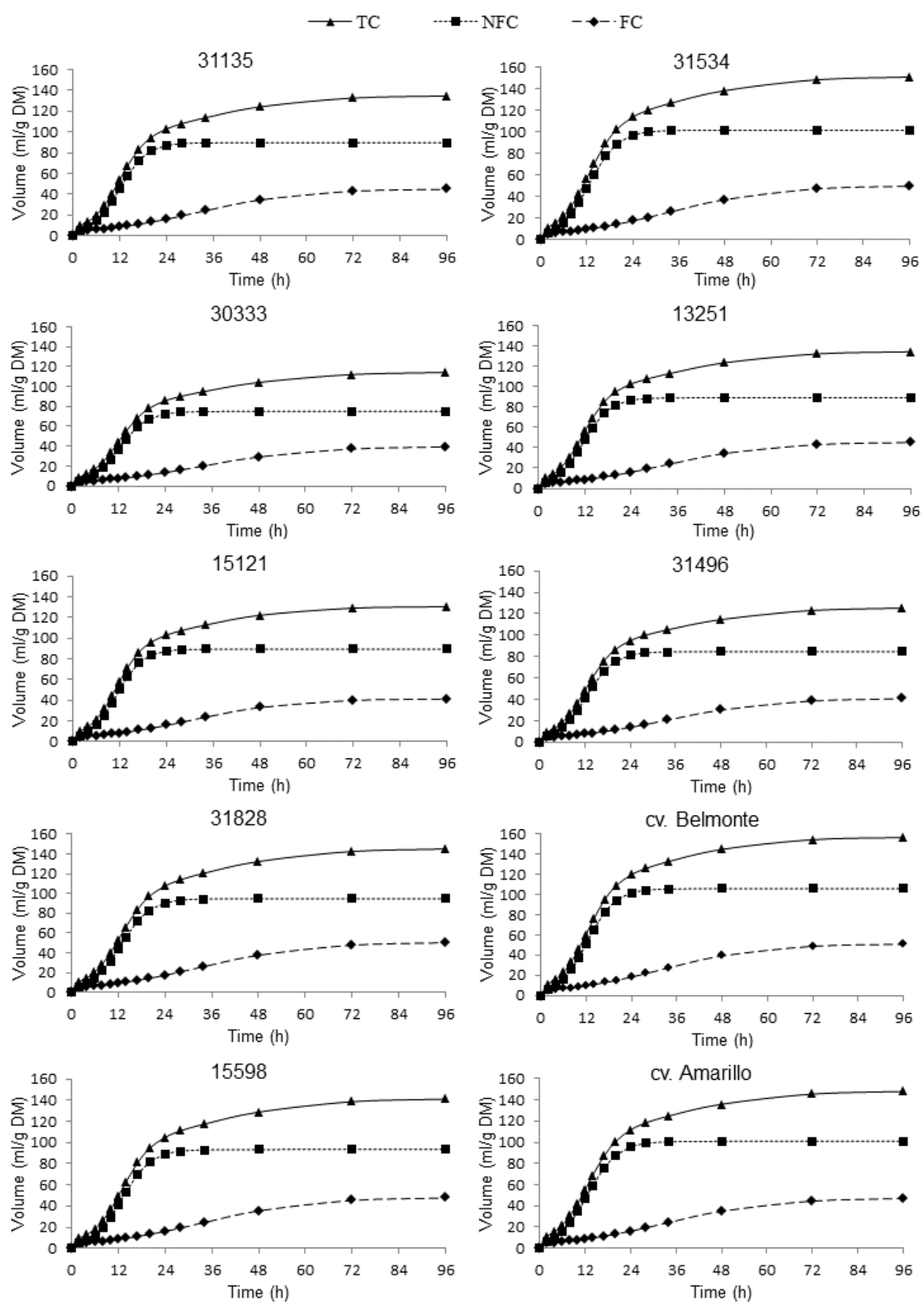

Figure 1 - Gas production curves for total carbohydrates (TC), non-fibrous carbohydrates (NFC) and fibrous carbohydrates (FC), relative to the genotypes of Arachis.

For subgroup III, consisting of accessions 31828, 31534 and cv. Belmonte, minimal similarity was obtained, at $72 \%$, with the greatest similarity observed for accessions 31828 and 31534, which presented the lowest average Euclidean distance (1.30). This subgroup can be considered of higher nutritional value for presenting the highest values of Deg48 and Kd rates.

Accessions 30333 and 31496 formed subgroup IV, which showed $71 \%$ similarity and was characterized by higher contents of CP, lower NDF content and low Kd rates.

In contrast, subgroup $\mathrm{V}$, consisting of accession 15598 and cv. Amarillo, showed similarity of $89 \%$, demonstrating large nutritional similarity between these genotypes. However, this subgroup showed the highest contents of NDF, the lowest values of Deg48 and lower Kd rates, assessed as nutritionally inferior compared with the other subgroups (Table 5). 
Table 5 - Groups of genotypes of forage peanut, average Euclidean distances and average variables in each group formed by the hierarchical agglomerative clustering method of Complete Linkage, based on standardized average Euclidean distance

\begin{tabular}{|c|c|c|c|c|c|}
\hline \multirow[t]{2}{*}{ Items } & \multicolumn{5}{|c|}{ Groups } \\
\hline & I & II & III & IV & V \\
\hline \multirow[t]{2}{*}{ Genotypes } & 31135 & 15121 & 31828 & 30333 & 15598 \\
\hline & $\begin{array}{c}13251 \\
-\end{array}$ & $\begin{array}{l}- \\
-\end{array}$ & $\begin{array}{c}31534 \\
\text { cv. Belmonte }\end{array}$ & $\begin{array}{c}31496 \\
-\end{array}$ & cv. Amarillo \\
\hline Distances & 1.89 & 6.80 & 6.02 & 6.08 & 2.40 \\
\hline NDF (\% DM) & 55.2 & 53.2 & 54.0 & 51.4 & 54.3 \\
\hline Deg 48 (\%) & 46.2 & 47.5 & 49.7 & 46.1 & 44.1 \\
\hline $\mathrm{Kd}\left(\mathrm{h}^{-1}\right)$ & 0.060 & 0.082 & 0.081 & 0.058 & 0.049 \\
\hline C1 $\left(h^{-1}\right)$ & 0.071 & 0.074 & 0.066 & 0.068 & 0.065 \\
\hline
\end{tabular}

CP - crude protein; NDF - neutral detergent fiber; Deg48 - in vitro degradability within 48 hours of incubation; kd - degradation rate of insoluble potentially degradable fraction; C1 - degradation rate for the NFC fraction.

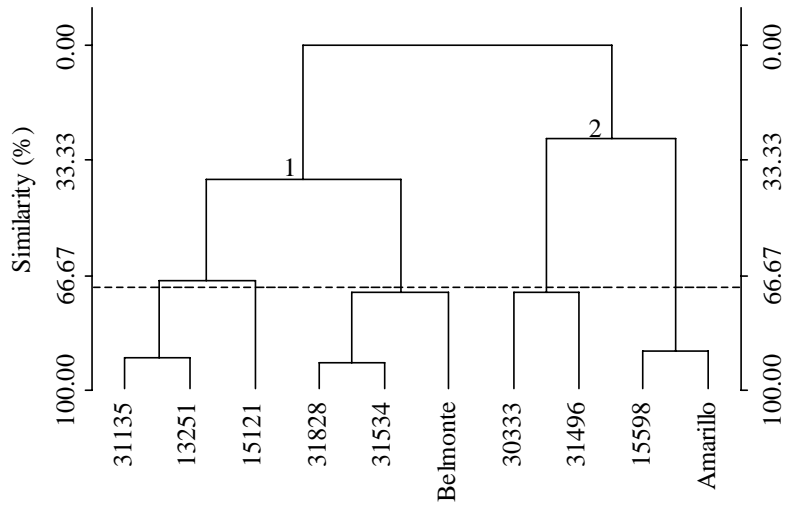

Figure 2 - Similarity dendrogram for the nutritional value of the ten genotypes of forage peanut.

Forages with high degradation potential indicate good nutritional value, since they can provide rapid and abundant availability of nutrients to the microorganisms in the rumen. But low rates of ruminal degradation may reduce DM intake and energy availability, which limits the productive performance of animals (Barnes et al., 2007). Khazaal et al. (1995), evaluating parameters of chemical composition, in vitro and in situ degradation as well as gas production in the prediction of voluntary intake, reported that consumption was significantly $(\mathrm{P}<0.05)$ related to the in vitro degradability at 48 hours $(r=0.75)$, and degradation rate $(r=0.66)$ of the forage.

\section{Conclusions}

The genotypes studied exhibit variations in the nutritional characteristics evaluated, and were grouped into distinct subgroups. Accessions 31828, 31534, 15121 and cv. Belmonte stood out nutritionally among the remaining genotypes evaluated, depicting themselves as promising for the utilization in ruminant feeding.

\section{References}

AFFONSO, B.A.; FERREIRA, O.G.L.; MONKS, P.L. et al. Rendimento e valor nutritivo da forragem outonal de amendoim-forrageiro. Ciência Animal Brasileira, v.8, n.3, p.385-395, 2007.

AZEVÊDO, J.A.G.; PEREIRA, J.C.; CARNEIRO, P.C.S. et al. Avaliação da divergência nutricional de variedades de cana-deaçúcar (Saccharum spp.). Revista Brasileira de Zootecnia, v.32, n.6, p.1431-1442, 2003.

BARNES, R.F.; NELSON, C.J.; MOORE, K.J. Forages: the science of grassland and agriculture. 6.ed. Blackwell: Ames, 2007. v.2, 556 .

CABRAL, L.S.; VALADARES FILHO, S.C.; DETMANN, E. et al. Composição químico-bromatológica, produção de gás, digestibilidade in vitro da matéria seca e NDT estimado da silagem de sorgo com diferentes proporções de panículas. Revista Brasileira de Zootecnia, v.32, n.5, p.1250-1258, 2003.

CAMPOS, F.P.; BOSE, M.L.V.; BOIN, C. et al. Avaliação do sistema de monitoramento computadorizado de digestão in vitro. 3. Desaparecimento da matéria seca e/ou FDN pela produção de gás. Revista Brasileira de Zootecnia, v.29, n.2, p.537-544, 2000.

CARNEIRO, J.C.; VALENTIM, J.F.; PESSÔA, G.N. Avaliação agronômica do potencial forrageiro de Arachis spp. nas condições ambientais do Acre. In: REUNIÃO ANUAL DA SOCIEDADE BRASILEIRA DE ZOOTECNIA, 37., 2000, Viçosa. Anais... Viçosa, MG: Sociedade Brasileira de Zootecnia/Gmosis, [2000]. (CD-ROM).

DETMANN, E.; SILVA, J.F.C.; VÁSQUEZ, H.M. et al. Cinética da degradação ruminal dos carboidratos de quatro gramíneas tropicais em diferentes idades de corte e doses de adubação nitrogenada: Técnica de produção de gases. Revista Brasileira de Zootecnia, v.38, n.1, p.149-158, 2009.

EVANGELISTA, A.R.; SALES, E.C.J.; TEIXEIRA, J.C. et al. Degradabilidade ruminal da matéria seca e proteína bruta de cultivares de alfafa (Medicago sativa L.). Ciência e Agrotecnologia, v.26, n.6, p.1281-1288, 2002.

GETACHEW, G.; ROBINSON, P.H.; DEPETERS, E.J. et al. Relationship between chemical composition, dry matter degradation and in vitro gas production of several ruminant feeds. Animal Feed Science and Technology, v.111, n.1-4, p.57-71, 2004.

HALL, M.B. Neutral detergent-soluble carbohydrates Nutritional relevance and analysis. Gainesville: University of Florida, 2000. 76p. (Bulletin, 339)

KHAZAAL, K.; DENTINHO, M.T.; RIBEIRO, J.M. et al. Prediction of apparent digestibily and voluntary intake of hays fed to sheep: comparison between using fibre components, in vitro 
digestibility or characteristics of gas production or nylon bag degradation. Journal of Animal Science, v.61, n.3, p.527-538, 1995.

LENZI, A.; CECATO, U.; MACHADO FILHO, L.C.P. et al. Produção e qualidade do pasto de coastcross consorciado ou não com amendoim forrageiro com ou sem aplicação de nitrogênio. Arquivo Brasileiro de Medicina Veterinária e Zootecnia, v.61, n.4, p.918-926, 2009.

MAURÍCIO, R.M.; MOULD, F.; DHANOA, M.S. et al. A semiautomated in vitro gas production technique for ruminants feedstuff evaluation. Animal Feed Science and Technology, v.79, n.4, p.321-330, 1999.

MAURÍCIO, R.M.; PEREIRA, L.G.R.; GONCALVES, L.C. et al. Relação entre pressão e volume para implantação da técnica in vitro semi-automática de produção de gases na avaliação de forrageiras tropicais. Arquivo Brasileiro de Medicina Veterinária e Zootecnia, v.55, n.2, p.216-219, 2003.

MINSON, J.G. Influence of sward characteristics on diet selection and herbage intake by the grazing animal. In: HACKER, J.B. (Ed.). Nutritional limits to animal production from pastures. Farnham Royal: CSIRO, 1982. p.169-174.

RUIZ, M.A.; SANTANA, J.C. Adaptabilidade e produtividade de Arachis sp. no extremo sul da Bahia. In: ENCONTRO LATINO AMERICANO DE ESPECIALISTAS EM ARACHIS, 4., 2004, Brasília. Anais... Brasília: Encontro Latino Americano de Especialistas em Arachis/Gmosis, [2004]. (CD-ROM).

NASCIMENTO, I.S.; MONKS, P.L.; VAHL, L.C. et al. Aspectos qualitativos da forragem de amendoim forrageiro cv. Alqueire1 sob manejo de corte e adubação PK. Revista Brasileira de Agrociência, v.16, n.1-4, p.117-123, 2010.

NASCIMENTO JÚNIOR, D.; VILELA, H. Pastagens: produção de sementes. Viçosa, MG: Centro de Ciências Agrárias, Departamento de Zootecnia, 1995. 133p.

PIZARRO, E.A.; CARVALHO, M.A.; VALLS, J.F. et al. Arachis spp.: evaluación agronomica en areas bajas del cerrado. In: REUNIÓN DE SABANAS, 1., 1992, Cali. Anais... Cali: Red Internacional de Evaluación de Pastos Tropicales, 1992. p.353-356.

SÁ, J.F.; PEDREIRA, M.S.; SILVA, F.F. et al. Cinética da fermentação in vitro do capim-Marandu em diferentes idades de corte. Acta Scientiarum Animal Sciences, v.33, n.3, p.225-231, 2011.
SCHOFIELD, P.; PELL, A.N. Measurement and kinetic analysis of the neutral detergent-soluble carbohydrate fraction of legumes and grasses. Journal of Animal Science, v.73, n.12, p.3455-3463, 1995.

SCHOFIELD, P.; PITT, R.E.; PELL, A.N. Kinetic of fiber digestion from in vitro gas production. Journal of Animal Science, v.72, n.11, p.2980-2991, 1994.

SAMPAIO, I.B.M.; PIKE, D.J.; OWEN, E. Optimal design for studying dry matter degradation in the rumem. Arquivo Brasileiro de Medicina Veterinária e Zootecnia, v.47, n.3, p.373-383, 1995.

SENGER, C.C.D.; MUHLBACH, P.R.F.; SANCHEZ, L.M.B. et al. Comparação entre os métodos químico, in situ e in vitro para estimativa do valor nutritivo de silagens de milho. Ciência Rural, v.37, n.3, p.835-840, 2007.

SILVA, D.J.; QUEIROZ, A.C. Análise de alimentos: métodos químicos e biológicos. 3.ed. Viçosa, MG: Universidade Federal de Viçosa, 2002. 235p.

SILVA, V.P.; ALMEIDA, F.Q.; MORGADO, E.S. et al. Digestibilidade dos nutrientes de alimentos volumosos determinada pela técnica dos sacos móveis em eqüinos. Revista Brasileira de Zootecnia, v.38, n.1, p.82-89, 2009.

STAPLES, C.R.; EMANUELE, S.M.; PRINE, G.M. Intake and nutritive value of Florigraze Rhizoma Peanut silage for lactating dairy cows. Journal Dairy Science, v.80, n.1, p.541-549, 1997.

THEODOROU, M.K.; WILLIAMS, B.A.; DHANOA, M.S. et al. A new gas production method using a pressure transducer to determine the fermentation kinetics of ruminal feeds. Animal Feed Science and Technology, v.48, n.12, p.185-197, 1994.

VALADARES FILHO, S.C.; MAGALHÃES, K.A.; ROCHA JÚNIOR, V.R. et al. Tabelas brasileiras de composição de alimentos para bovinos. 2.ed. Viçosa, MG: Universidade Federal de Viçosa, 2006. 300p.

VALENTIM, J.F.; ANDRADE, C.M.S.; MENDONÇA, H.A. et al. Velocidade de estabelecimento de acessos de amendoim forrageiro na amazônia ocidental. Revista Brasileira de Zootecnia, v.32, n.6, p.1569-1577, 2003.

VAN SOEST, P.J. Nutritional ecology of the ruminant. 2.ed. Ithaca: Cornell University Press, 1994. 476p.

VELOSO, C.M.; RODRIGUEZ, N.M.; CARVALHO, G.G.P. et al. Degradabilidade ruminal da matéria seca e da proteína bruta de folhas e folíolos de forrageiras tropicais. Revista Brasileira de Zootecnia, v.35, n.2, p.613-617, 2006. 